DOi: $10.5578 /$ fmbd.66838

\title{
Physiological Responses Of Epiphytic Lichens To The Urban And Rural Environment In The City Of Bursa (Turkey)
}

\author{
Şaban Güvenç, Gamze Yıldız, Egemen Dere \\ Uludag University, Faculty of Arts and Science, Department of Biology, 16059 Görükle kampüsü, Nilufer-Bursa. \\ E-posta:saban@uludag.edu.tr ( ${ }^{*}$ Corresponding author)
}

\section{Keywords \\ Lichens; Physiological parameters; Air pollution; Glutathione S-transferase activity; Bursa}

\begin{abstract}
This study was designed with an aim to observe the effect on the physiological parameters of epiphytic lichens of the climatic conditions, population and traffic activity in the sites. The study was carried out in thalli of Evernia prunastri (L.) Ach., Parmelia sulcata Taylor and Pseudevernia furfuracea (L.) Zopf collected from the urban and rural area. Six parameters (total protein, total carbohydrate, Chl-a, Chl-b, carotenoid content and glutathione S-transferase (GST) activities were measured in thalli of epiphytic lichens. Protein content and GST activity were showed a negative correlation with rainfall and humidity, while positively correlation with temperature, population and the number of motor vehicles. GST activity was increased by increasing the level of pollution in sites, and Chl-a content decreased. Chl-a and carotenoids content were showed a positive correlation with rainfall and humidity, while negatively correlated with temperature, population and the number of motor vehicles. Total carbohydrate and $\mathrm{Chl}$-b content in thalli of three epiphytic lichen species were not a significant correlation with climatic and anthropogenic parameters.
\end{abstract}

\section{Bursa Şehrinde Kentsel ve Kırsal Çevreye Epifitik Likenlerin Fizyolojik Tepkileri}

\begin{abstract}
Özet
Bu çalışma üç farklı alandaki iklim şartları, nüfus ve trafik aktivitesinin epifitik likenlerin fizyolojik parametreleri üzerine etkisini gözlemlemek amacı ile tasarlanmıştır. Çalışma kentsel ve kırsal alandan toplanan Evernia prunastri (L.) Ach., Parmelia sulcata Taylor ve Pseudevernia furfuracea (L.) Zopf liken örnekleri üzerinde yürütülmüştür. Epifitik likenlerin tallusunda altı farklı fizyolojik parametre (toplam protein, toplam karbonhidrat, Chl-a, Chl-b, karotenoid içeriği ve glutatyon S-transferaz (GST) aktivitesi) ölçülmüştür. Protein içeriği ve GST aktivitesi yağış ve nem ile negatif korelasyon gösterirken sıcaklık, nüfus ve motorlu taşıtların sayısı ile pozitif korelasyona göstermektedir. GST aktivitesi incelenen alanlarda kirlilik düzeyinin artması ile artmış ve Chl-a içeriği ise azalmıştır. Chl-a ve karotenoid içerik yağış ve nem ile pozitif, sıcaklık, nüfus ve motorlu araç sayısı ile negatif korelasyon göstermektedir. Epifitik liken türlerinin toplam karbonhidrat ve Chl-b içeriği ile iklimsel ve insan kaynaklı parametreler arasında istatistiksel olarak anlamlı bir ilişki bulunmamıştır.
\end{abstract}

\section{Introduction}

Lichens are highly sensitive organisms to the environmental stress and especially to the atmospheric pollutants (Nimis et al. 2000; Conti and Cecchetti 2001; Giordano et al. 2005). The pollutants as $\mathrm{NOx}, \mathrm{CO}_{2}, \mathrm{CO}$ and $\mathrm{SO}_{2}$ released by vehicle traffic is one of the main sources of air pollution in the urban areas and roadside (Gilbert et al. 2003). Phytotoxic gases emitted from motor vehicles is reduced the diversity and changed the composition of epiphytic lichens in the urban environments and roadside (Giordani et al. 2002; Loppi et al. 2002).

Lichens are good indicators of habitat changes, providing an integrated measure of all disturbances present in their environment (Pinho et al. 2004). The diversity of epiphytic lichens, the composition of lichen communities, the accumulation of trace 
elements and the response of physiological parameters in sensitive species can be used as indicators of environmental stress (Garty et al. 2001; Paoli et al. 2011).

There are several papers a correlation between changes in photosynthetic pigment content of lichens and atmospheric pollution (Carreras and Pignata 2001; Ra et al. 2005; Riddell et al. 2012; Seed et al. 2013). Physiological parameters reflect the health status of lichen thalli, offer rapid information on the effects of stress and allow monitoring of the biological effects of air pollution (Munzi et al. 2009).

This study was aimed to observe the effect on the physiological parameters of foliose lichen $P$. sulcata, and fruticose lichens $E$. prunastri and $P$. furfuracea collected from the urban and rural area of the climatic conditions, population and traffic activity in the sites.

\section{Material and Method}

\subsection{Study Area and Sampling}

The city of Bursa is an industrial city located $\left(40^{\circ} \mathrm{N}\right.$ $28-30^{\circ} \mathrm{E}$ ) in the southeast of the Marmara region of Turkey. Bursa Province is one of the most rapid developing cities of Turkey with population growth above the average. The most important factor in this rapid population increase is continuously receives migration. The province is fifth biggest city of Turkey One of the priority environmental problems in Bursa is air pollution. The major reasons of this problem is use of fuel for heating purposes and industrial activities. In addition, include air pollutants emitted from the motor vehicle exhausts, and wrong placement of industry, and unplanned urbanization. Air pollution in Bursa occurs particularly in winter season (Table 1) (Karaer, 2011). The average $\mathrm{SO}_{2}$ concentration measured during the winter months (236.8 $\mathrm{\mu g} / \mathrm{m} 3$ ) 1988-1999 period in Bursa was approximately 6 times of average in the summer months $(38.7 \pm 6.6 \mu \mathrm{g} / \mathrm{m} 3)$. In 1992, natural gas was introduced in the city of Bursa. It was increased use of over the years. The average $\mathrm{SO}_{2}$ concentration was measured as $73.2 \mu \mathrm{g} / \mathrm{m} 3$ in 1999 (Taşdemir, 2002). $\mathrm{SO}_{2}$ concentration has fallen even more in the following years and was measured to be 10 $(\mu / \mathrm{m} 3)$ in 2010 . The concentration of particular matterial (PM) was showed a tendency to decrease in the years of 1990-2005 in the province of Bursa. The concentration of PM was tended to increase in the years from 2007 to 2009, and was measured 61 $(\mu / \mathrm{m} 3)$ in 2010 (Anonymous, 2011).

The air pollution is the third priority problem in the Nilüfer district. The air pollution occurs depending on the use of coal for heating purposes, and from industry in the Nilüfer district. In addition, there are smell problems resulting from the wastewater treatment plant (BUSKI) in the Nilüfer district. Nilufer district is the second among the districts in Bursa where heavy industry is located. The air pollution problems are sourced from the textiles, steel, and foundry industry. Those industries are located at Bursa chamber of commerce and industry (BTSO), Organized industrial area (OSB), Nilufer Industry Associations Organized (NOSAB), Hasanağa Industry Associations Organized (HOSAB) within this district (Karaer, 2011).

Air pollutants emitted from the motor vehicles is as important as pollutants resulting from residential and industrial facilities. $70-90 \%$ of carbon dioxide emissions, $40-70 \%$ of nitrogen oxide emissions, $50 \%$ of the emissions of hydrocarbons, $100 \%$ of lead emissions at the air pollution in the city of Bursa are caused by motor vehicles. The number of vehicles in Bursa Province is increasing rapidly in parallel with the population. The number of vehicles registered to traffic in Bursa is 538.598 units at the end of the year 2010 (Table 2). The most important factors in the city's air pollution is vehicles and the impact of vehicle is $45 \%$. According to the Address Based Population Registration System, the population of Bursa province in 2010 year is 2,605,495 and population density is 241 person / km2 (Karaer, 2011). 
Tabe 1. The average monthly values $\left(\mu \mathrm{g} / \mathrm{m}^{3}\right)$ of airborne pollutant gases in Bursa province and Nilufer district in 2012.

\begin{tabular}{|c|c|c|c|c|c|c|c|c|c|c|}
\hline \multirow{2}{*}{ Months } & \multicolumn{5}{|c|}{ Bursa } & \multicolumn{5}{|c|}{ Nilüfer } \\
\hline & $\mathrm{SO}_{2}$ & NO & $\mathrm{NO}_{2}$ & $\mathrm{NO}_{x}$ & $\mathrm{CO}$ & $\mathrm{SO}_{2}$ & NO & $\mathrm{NO}_{2}$ & NOx & CO \\
\hline January & 72 & 80 & 65 & 101 & 839 & 23 & 121 & 62 & 183 & 1469 \\
\hline February & 82 & 50 & 45 & 95 & 664 & 13 & 41 & 52 & 93 & 653 \\
\hline March & 58 & 35 & 34 & 69 & 654 & 7 & 24 & 39 & 63 & 334 \\
\hline April & 124 & 19 & 27 & 61 & 580 & 5 & 11 & 27 & 38 & - \\
\hline May & 275 & 39 & 35 & 72 & 905 & 15 & 5 & 22 & 27 & - \\
\hline June & 290 & 46 & 40 & 86 & 300 & - & 4 & 28 & 32 & 145 \\
\hline July & 22 & 2 & 30 & 32 & 273 & - & 2 & 30 & 32 & 140 \\
\hline August & 36 & 25 & 34 & 59 & 271 & 32 & 3 & 36 & 39 & 161 \\
\hline September & 27 & 24 & 37 & 61 & 305 & 8 & 3 & 41 & 44 & 234 \\
\hline October & 51 & 23 & 38 & 60 & 615 & 13 & 3 & 42 & 45 & 495 \\
\hline November & 52 & 23 & 16 & 41 & 900 & 12 & 3 & 3 & 6 & 736 \\
\hline December & 55 & 23 & 18 & 44 & 1134 & 14 & 3 & 3 & 6 & 1091 \\
\hline Mean & 95 & 32 & 35 & 65 & 620 & 14 & 19 & 32 & 51 & 546 \\
\hline
\end{tabular}

Tabe 2. Variation in the number of vehicles and population in the study area in 2008-2012 years. a: (Anonymous, 2012); b: (Anonymous, 2013)

\begin{tabular}{|c|c|c|c|c|c|c|c|}
\hline \multirow{2}{*}{ Years } & \multicolumn{2}{|c|}{ Bursa } & \multicolumn{2}{|c|}{ Nilüfer } & \multirow{2}{*}{$\begin{array}{l}\begin{array}{c}\text { Bursa-Uludağ road } \\
\text { at Yiğitali in Uludağ }\end{array} \\
\text { Traffic }^{\mathrm{a}}\end{array}$} & \multicolumn{2}{|c|}{ Hüseyinalan in Uludağ } \\
\hline & Traffic $^{a}$ & Population $^{b}$ & Traffic $^{a}$ & Population $^{b}$ & & Traffic & Population $^{b}$ \\
\hline 2008 & 498.087 & 2.507 .963 & 38.183 & 270.502 & 1.469 & 世 Г్ & 136 \\
\hline 2009 & 513.498 & 2.550 .645 & 38.581 & 282.991 & 1.438 & 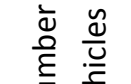 & 120 \\
\hline 2010 & 538.598 & 2.605 .495 & 40.459 & 289.911 & 1.462 & $\frac{\bar{\Sigma}}{\bar{\Sigma}} \stackrel{\bar{d}}{\bar{d}}$ & 121 \\
\hline 2011 & 574.926 & 2.652 .126 & 78.961 & 316.540 & 1.425 & 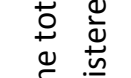 & 128 \\
\hline 2012 & 607.585 & 2.688 .171 & 78.865 & 339.667 & 5.081 & F & 115 \\
\hline Mean & 546.539 & 2.600 .880 & 55.010 & 299.922 & 2.175 & 291 & 124 \\
\hline
\end{tabular}

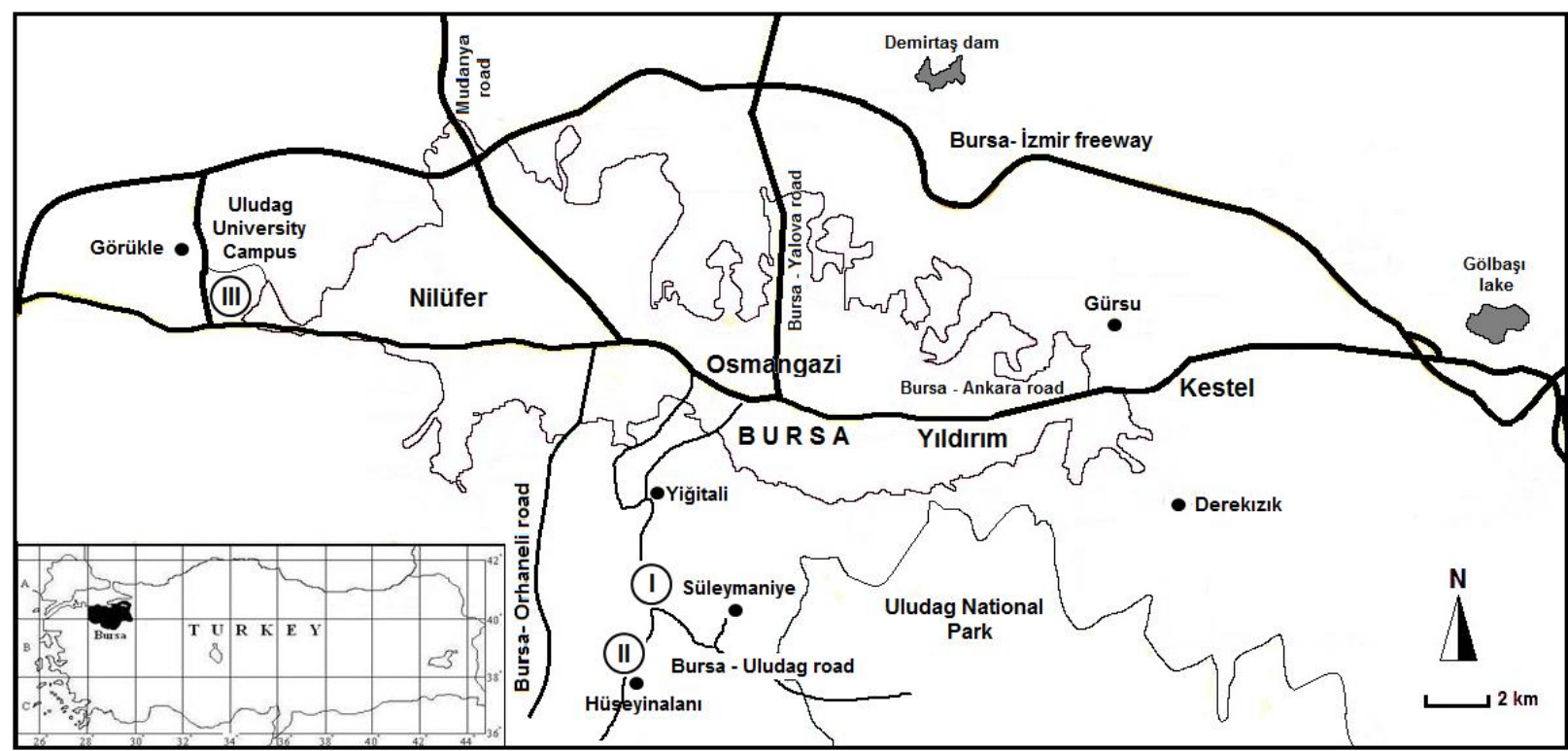

Figure 1. The study area and locations. 
In this study, the effects on the physiological parameters of lichens of air pollution caused by urbanization and traffic congestion were investigated. For this purpose, three region with different levels of urbanization, population density, and motor vehicles density in the different distances from the city center around the city of Bursa was chosen (Fig. 1, Table 3). In the city of Bursa is dominated the Mediterranean climate. The average annual precipitation is $707.5 \mathrm{~mm}$, and the average annual temperature is $14.6{ }^{\circ} \mathrm{C}$ with an average humidity of $69.7 \%$ (Fig. 2) (TSMS, 2018). In generally, the north-winds is dominated in Bursa. Whereas the dominant wind direction in summer is $\mathrm{N} 49^{\circ} \mathrm{E}(61.3 \%), \mathrm{N} 53^{\circ} \mathrm{E}(53.6 \%)$ in autumn, and $\mathrm{N} 72^{\circ} \mathrm{E}$ $(62.8 \%)$ in the winter, the dominant wind direction in spring is $S 74^{\circ} \mathrm{W}(47.6 \%)$ (Öztürk, 2010).

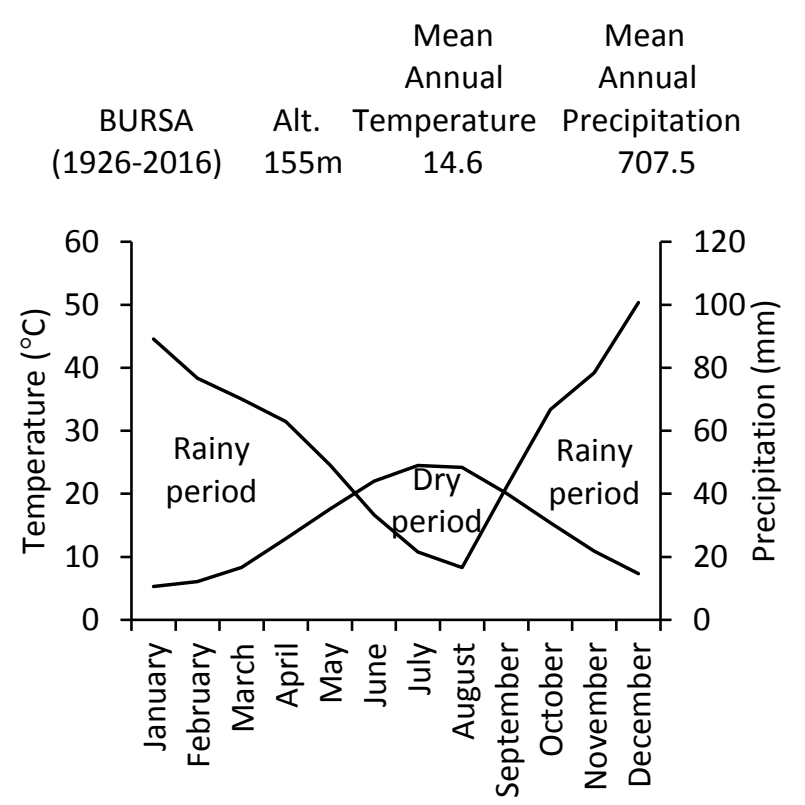

Figure 2. The climate diagram of Bursa city.

Table 3. Climatic and anthropogenic characteristics of the sites where the lichen samples collected.

\begin{tabular}{|c|c|c|c|}
\hline & \multicolumn{3}{|c|}{ Sites } \\
\hline & I & II & III \\
\hline & $\begin{array}{c}4 \mathrm{~km} \text { after Yiğitali village } \\
\text { on Uludag road }\end{array}$ & Hüseyinalanı & $\begin{array}{l}\text { Uludag University } \\
\text { Campus }\end{array}$ \\
\hline Location & $\begin{array}{l}\text { A rural mountain area } \\
\text { (roadside) }\end{array}$ & A rural mountain village & Urban area \\
\hline $\begin{array}{l}\text { Distance from city } \\
\text { center }\end{array}$ & $14 \mathrm{~km}$ & $17 \mathrm{~km}$ & $20 \mathrm{~km}$ \\
\hline $\begin{array}{l}\text { The main source of } \\
\text { air pollution }\end{array}$ & Motor vehicles. & $\begin{array}{l}\text { A small number motor } \\
\text { vehicles, and coal burning } \\
\text { for heating purposes in } \\
\text { winter. }\end{array}$ & $\begin{array}{l}\text { This area is a region that } \\
\text { is felt the most of the } \\
\text { negative impacts of } \\
\text { urbanization and motor } \\
\text { vehicles on air quality }\end{array}$ \\
\hline Coordinate & $40^{\circ} 08^{\prime} 00^{\prime \prime} \mathrm{N}-29^{\circ} 01^{\prime} 28^{\prime \prime} \mathrm{E}$ & $40^{\circ} 07^{\prime} 12^{\prime \prime} \mathrm{N}-29^{\circ} 01^{\prime} 05^{\prime \prime} \mathrm{E}$ & $40^{\circ} 14^{\prime} 10^{\prime \prime} \mathrm{N}-28^{\circ} 52^{\prime} 55^{\prime \prime} \mathrm{E}$ \\
\hline Altitude & $900 m$ & $994 m$ & $128 m$ \\
\hline $\begin{array}{l}\text { Mean annual } \\
\text { precipitation }\left(\mathrm{mm}^{3}\right)\end{array}$ & 1119 & 1119 & 677 \\
\hline Humidity (\%) & 71 & 71 & 67 \\
\hline $\begin{array}{l}\text { Mean annual } \\
\text { temperature }\left({ }^{\circ} \mathrm{C}\right)\end{array}$ & 11 & 11 & 15 \\
\hline $\begin{array}{l}\text { Population (Number } \\
\text { of persons) }\end{array}$ & - & 124 & 299.922 \\
\hline $\begin{array}{l}\text { The number of } \\
\text { vehicles }\end{array}$ & 2175 & 291 & 55.010 \\
\hline
\end{tabular}

Foliose lichen $P$. sulcata, fruticose lichens $E$. prunastri and $P$. furfuracea were selected as research material for have a wide distribution on the trunk of Quercus sp in Bursa province (Oran and
Öztürk 2012) and to be sensitive to air pollution (van Dobben and Braak 1999). Lichen samples from Sites I and II were collected on the trunk of Quercus sp. from the roadside on 14 October, 2008. E. prunastri 
and $P$. sulcata were collected on the trunk of Quercus sp. and $P$. furfuracea on Pinus sp. from the Site III, on 17 February, 2009.

\subsection{Experimental Procedure}

Total Soluble Carbohydrate was assayed by anthrone-sulphuric acid method (Laurentin and Edwards 2003) which involved extraction with $15 \%$ trichloroacetic acid. The absorbance was measured at $620 \mathrm{~nm}$.

Total protein content was determined spectrophotometrically at $595 \mathrm{~nm}$ and concentrations were calculated by comparing with a calibration curve of bovine serum albumin (Bradford, 1976).

Chlorophyll a (Chl-a) and chlorophyll b (Chl-b) contents of samples were determined in accordance with the Jeffrey and Humprey method (1975) with 90\% acetone as a solvent. Carotene was determined according to the Lichtenthaler and Wellburn (1985) method with $90 \%$ acetone.

\subsection{GST activity}

Freezed samples were homogenized 15 minutes after the addition cold buffer (potassium phosphate) at pH 6.7 (1/3 mass/volume) using a porcelain mortar. The homogenate was centrifuged at $9000 \mathrm{~g}$ for 40 minutes at $4^{\circ} \mathrm{C}$ (Ferrat et al. 2003). The supernatant was separated using a micropipette. The supernatant was used for determining GST enzyme activities. Care was taken to achieve homogenization, centrifuging and all enzymatic studies at $0-4^{\circ} \mathrm{C}$. Measurements were made using the method of Bowman et al. (1990) and Habig et al. (1974) with GSH and CDNB as a substrates. GST enzyme activity was determined by tracing the formation of the thioether link between the GSH catalyzed by the enzymes and CDNB in Cecil 5000- Spectrophotometer. The activity was measured as the absorbance change per minute at $340 \mathrm{~nm}$ at $25^{\circ} \mathrm{C}$.
The significance of differences among the sites of the physiological parameters of lichen species collected from the three field sites were evaluated by a one-way analysis of variance (ANOVA) with Tukey test. Statistical analyses were performed using SPSS for Windows (Version 22). To determine correlation between climatic conditions, population and traffic in the sites, with the physiological parameters of three lichen species were used to Pearson's correlation coefficient. The difference was considered to be significant at $p<0.05$.

\section{Results}

In this study, physiologic parameters of the foliose lichen $P$. sulcata and fruticose lichens $E$. prunastri and $P$. furfuracea were measured at different three localities and the results were given in Fig. 3.

Compared to variations in the total protein content for each lichen species between the sites, all lichen species showed similarities in the Site I and II, and the Site III was statistically significant and different from other sites. In contrast, variations in the total carbohydrate content for each lichen species are similar in site II and III, and is different in site I. The total protein content measured in thalli of $E$. prunastri and $P$. furfuracea is increasing with an increase in air pollution towards from the site I to III (Fig. 3).

Chl-a and carotenoid content measured in thalli of Parmelia sulcata showed no differences between the sites, and $E$. prunastri and $P$. furfuracea are significant differences, especially sites I and III. In terms of Chl-b, only $P$. furfuracea has significant differences between Site I and III. The lowest Chl-a content for each lichen species was measured in samples collected from Site III. Variation in the Chla content of $E$. prunastri and $P$. furfuracea between the sites was significant, $P$. sulcata was not. Especially, levels of Chl-a in thallus of $P$. furfuracea collected from urban areas (Site III) was decreased, and increased in a rural area (Site I and II). Indeed, the highest levels of Chl-a was measured at Site I in a rural area. GST activity for all lichen species showed similarities at the sites II and III, and

\subsection{Statistical Analyses}


especially were detected significant differences between sites I and III (Fig. 3).
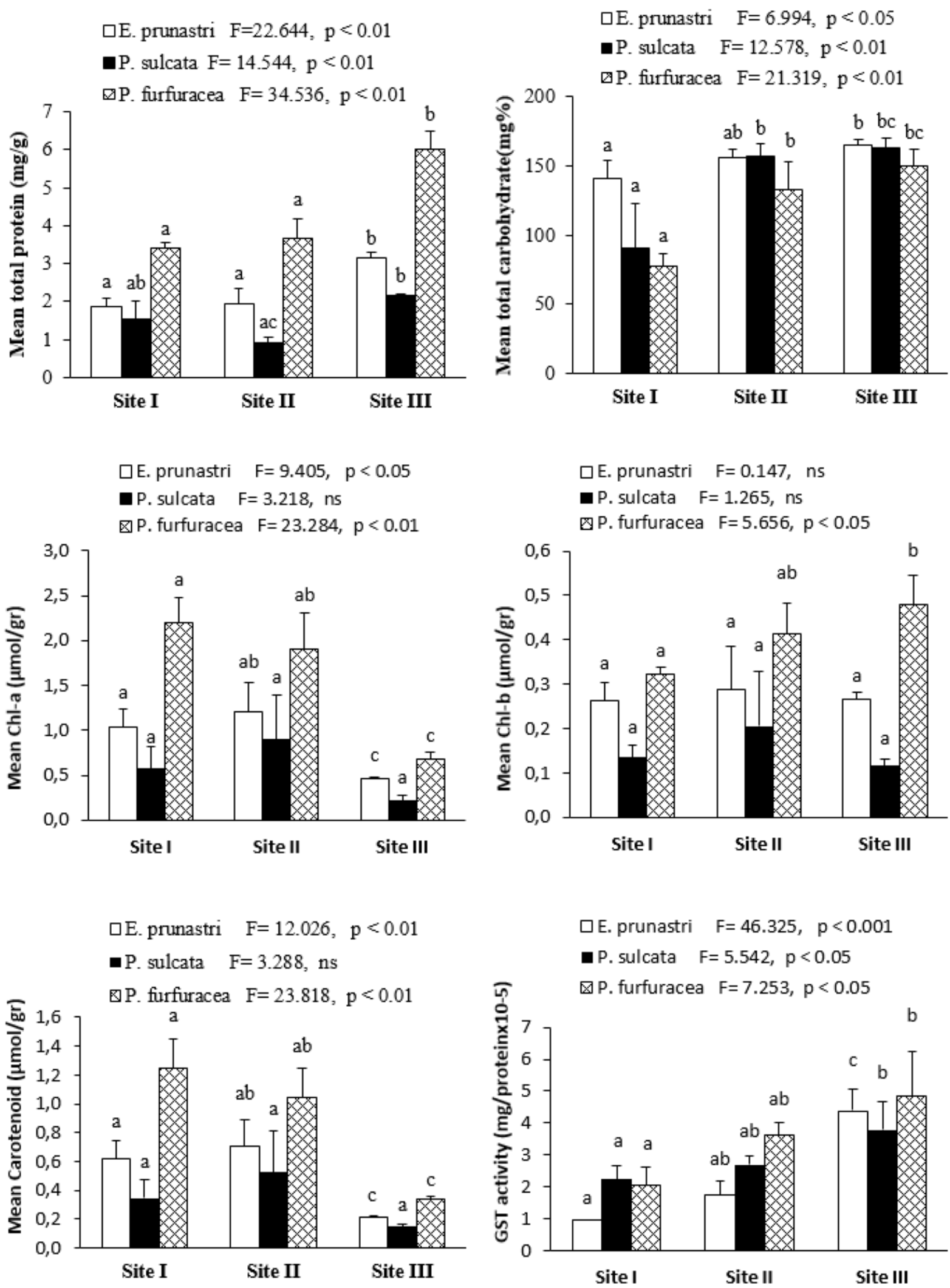

Figure 3. Comparison of the Mean \pm SD values by one-way ANOVA with Tukey test of the physiological parameters of lichen species collected from the three localities. 
Pearson's correlation coefficients between climatic and anthropogenic conditions in sites and the physiological parameters of three epiphytic lichens were given in Table 4. Protein content and GST activity for each epiphytic lichen species have been found to be a significant correlation with climatic parameters, population and traffic. Protein content and GST activity were showed a negative correlation with rainfall and humidity, while positively correlation with temperature, population and the number of motor vehicles. GST activity was increased by increasing the level of pollution in sites, and $\mathrm{Chl}$-a content decreased.

Table 4. Pearson's correlation between population and traffic with the physiological parameters in thalli of E. prunastri, $P$. sulcata, and $P$. furfuracea in rural and urban environmental conditions.

\begin{tabular}{|c|c|c|c|c|c|c|c|}
\hline E. prunstri & Sites & Protein & Carbohydrat & Chl-a & Chl-b & Carotenoid & GST \\
\hline Sites & 1 & $0.833^{* *}$ & $0.828^{* *}$ & -0.639 & 0.024 & $-0.686^{*}$ & $0.927^{* *}$ \\
\hline Altitude & $-0.811^{* *}$ & $-0.930^{* *}$ & -0.602 & $0.864^{* *}$ & 0.106 & $0.892^{* *}$ & $-0.917^{* *}$ \\
\hline Precipitation & $-0.866^{* *}$ & $-0.939^{* *}$ & -0.658 & $0.849^{* *}$ & 0.086 & $0.881^{* *}$ & $-0.944^{* *}$ \\
\hline Temperature & $0.866^{* *}$ & $0.939^{* *}$ & 0.658 & $-0.849^{* *}$ & -0.086 & $-0.881^{* *}$ & $0.944^{* *}$ \\
\hline Humidity & $-0.866^{* *}$ & $-0.939^{* *}$ & -0.658 & $0.849^{* *}$ & 0.086 & $0.881^{* *}$ & $-0.944^{* *}$ \\
\hline Population & $1.000^{* *}$ & $0.931^{* *}$ & 0.784 & $-0.894^{*}$ & -0.188 & $-0.917^{*}$ & $0.944^{* *}$ \\
\hline Traffic & $0.850^{* *}$ & $0.937^{* *}$ & 0.642 & $-0.855^{* *}$ & -0.092 & $-0.886^{* *}$ & $0.937^{* *}$ \\
\hline \multicolumn{8}{|l|}{ P. sulcata } \\
\hline Sites & 1 & 0.458 & $0.810^{* *}$ & -0.382 & -0.111 & -0.380 & $0.781^{*}$ \\
\hline Altitude & $-0.811^{* *}$ & $-0.832^{* *}$ & -0.429 & $0.667^{*}$ & 0.402 & $0.668^{*}$ & $-0.743^{*}$ \\
\hline Precipitation & $-0.866^{* *}$ & $-0.790^{*}$ & -0.506 & 0.636 & 0.363 & 0.637 & $-0.770^{*}$ \\
\hline Temperature & $0.866^{* *}$ & $0.790^{*}$ & 0.506 & -0.636 & -0.363 & -0.637 & $0.770^{*}$ \\
\hline Humidity & $-0.866^{* *}$ & $-0.790^{*}$ & -0.506 & 0.636 & 0.363 & 0.637 & $-0.770^{*}$ \\
\hline Population & $1.000^{* *}$ & $0.991^{* *}$ & 0.416 & -0.753 & -0.533 & -0.752 & 0.713 \\
\hline Traffic & $0.850^{* *}$ & $0.803^{* *}$ & 0.484 & -0.646 & -0.375 & -0.647 & $0.763^{*}$ \\
\hline \multicolumn{8}{|l|}{ P. furfuracea } \\
\hline Sites & 1 & $0.870^{* *}$ & $0.896^{* *}$ & $-0.887^{* *}$ & $0.805^{* *}$ & $-0.898^{* *}$ & $0.839^{* *}$ \\
\hline Altitude & $-0.811^{* *}$ & $-0.942^{* *}$ & -0.566 & $0.903^{* *}$ & -0.613 & $0.896^{* *}$ & -0.644 \\
\hline Precipitation & $-0.866^{* *}$ & $-0.955^{* *}$ & -0.639 & $0.925^{* *}$ & -0.663 & $0.921^{* *}$ & $-0.695^{*}$ \\
\hline Temperature & $0.866^{* *}$ & $0.955^{* *}$ & 0.639 & $-0.925^{* *}$ & 0.663 & $-0.921^{* *}$ & $0.695^{*}$ \\
\hline Humidity & $-0.866^{* *}$ & $-0.955^{* *}$ & -0.639 & $0.925^{* *}$ & -0.663 & $0.921^{* *}$ & $-0.695^{*}$ \\
\hline Population & $1.000^{* *}$ & $0.943^{* *}$ & 0.546 & $-0.931^{* *}$ & 0.508 & $-0.946^{* *}$ & 0.589 \\
\hline Traffic & $0.850^{* *}$ & $0.952^{* *}$ & 0.618 & $-0.920^{* *}$ & 0.649 & $-0.914^{* *}$ & $0.681^{*}$ \\
\hline
\end{tabular}

Correlation is significant at the $0.01\left({ }^{* *}\right)$ and 0.05 levels $\left({ }^{*}\right)$

Variations in Chl-a and carotenoid content in thalli of $E$. prunastri and $P$. furfuracea were found statistically significant. Variations in Chl-a and carotenoids content in both fruticose lichen species were showed a positive correlation with rainfall and humidity, while vegatively correlated with temperature, population and the number of motor vehicles. On the contrary, Carbohydrate and Chl-b content in thalli of three epiphytic lichen species were not a significant correlation with climatic and anthropogenic parameters.

\section{Discussion}

A study of 24 lichen species given from 29 localities in the city of Bursa, the city center is designated as lichen desert. Only a few crustose and foliose lichen species is located in a narrow struggle zone at around the city center. $P$. sulcata and $P$. furfuracea 
were collected from the struggle zone and normal zone in 1995 year (Öztürk et al. 1997). Foliose lichen $P$. sulcata, fruticose lichens $E$. prunastri and $P$. furfuracea are the most common epiphytic lichen species in all altitude in Uludag Mountain (Öztürk and Güvenç 2010).

The main pollutants that caused air pollution in urban environments, road sides and in areas close to the road is emitted gases from motor vehicles such as sulfur dioxide $\left(\mathrm{SO}_{2}\right)$, carbon monoxide (CO) and particularly nitrogen dioxide $\left(\mathrm{NO}_{2}\right)$ (Gilbert et al. 2007). The distribution and species composition of lichens was known to varied depending on air pollution and the environmental changes (Giordani, 2007; van Herk et al. 2002).

The total nitrogen content in lichens is shown to variations from species to species with increasing of the flow of traffic on the road. There was no effect on the nitrogen concentration of a nitrophytic lichen, Physcia adscendens (Fr.) H. Olivier, of traffic density on the road. On the other hand, the nitrogen concentration of a acidophytic lichen, Hypogymnia physodes (L.) Nyl., was significantly increases due to the traffic density on the roads (Gombert et al. 2003). The trunk pH of trees is higher in traffic areas due to the presence of pollutants such as alkaline dust particles and/or atmospheric amonium (Frati et al. 2006). It is known to cause an increase in eutrophic and basophilous lichens, and a decrease in oligotrophic and acidophytic ones (van Herk, 2001). A high correlation between the accumulation of nitrogen in lichens and the proximity to areas with a dense traffic has been established in urban areas. The traffic is the main cause for the decline in lichen diversity and abundance (Llop et al. 2012).

Air pollutants, especially $\mathrm{SO}_{2}$ and $\mathrm{NO}_{x}$ gases released from motor vehicles were observed to reduce the fluorescence of chlorophyll a in thalli of the foliose lichen Flavoparmelia caperata (L.) Hale (Tretiach et al. 2007). Another similar result was obtained from Usnea sp. In parallel to the increase of air pollutants emitted by road traffic was increased the content of $\mathrm{Chl}-\mathrm{a}+\mathrm{b}$ in thalli of Usnea sp, and degradation of Chla (Carreras et al. 1998). Evaluated the relationship between traffic pollution and total protein and photosynthetic pigment content (Chl-a, Chl-b and carotenoids) in thalli of Pyxine subcinerea Stirt. in
Himalaya, the Chl-a, Chl-b and carotenoids content in thalli of $P$. subcinerea was decreased due to the traffic density on the roads, and was shown an increase in protein content (Shukla and Upreti 2008).

Another study investigated the effect of urbanization and traffic density on physiology of foliose lichen Phaeophyscia hispidula (Ach.) Essl., the concentration of total chlorophyll was decreased in the samples from contaminated sites, and was determined an increase in protein content (Shukla and Upreti 2007).

The lichen $E$. prunastri is one of the most widely used species for biomonitoring purposes, either as a bioindicator of air quality or as a bioaccumulator of atmospheric deposition (Ayrault et al. 2007). Low chlorophyll content and high chlorophyll degradation in $E$. prunastri was measured in the examples of the geothermal of Tuscany. $\mathrm{H}_{2} \mathrm{~S}$ has been pointed out as the main pollutant responsible for lichen decline around power plants (Paoli and Loppi 2008). A low pH is known to be responsible for chlorophyll degradation (Garty et al. 1992), and photosynthetic efficiency of lichens has been found to decrease under low pH conditions (Gauslaa et al. 1996). Similarly, the lowest chlorophyll content was detected in lichens from the urban areas. Photosynthetic rates were extremely low in industrial sites in the urban areas, whereas the highest values were obtained for the rural areas (Garty et al. 2001). Chl-a content in thalli of $E$. prunastri was found to be a decrease in the vicinity of residential zones, major transport routes and an oil refinery. Chlorophyll content of $E$. prunastri has been shown to have a negatively correlated with the ratio of nitrophilous lichens, and a positively correlation with the epiphytic lichen diversity (Lackovic et al. 2013). The pollutants emitted by road traffic was found to reduce the content of $\mathrm{Chl}$ a, Chl-b and total carotenoids in thalli of E. prunastri, and to increase in the total nitrogen content (Frati et al. 2006).

$P$. sulcata was found to be the most tolerant species to air pollution (Haffner et al. 2001). The chlorophyll content of $P$. sulcata was found to have a gradual decrease from urban to rural sites. Nevertheless, The highest rates of net 
photosynthesis were measured at urban, and the lowest at rural stations (von Arb et al. 1990).

Similar to our results, maximum net carbon uptakes in P.sulcata was highest at polluted sites in winter than summer within sites by Ra et al.(2005). $\mathrm{CO}_{2}$ uptake was similar at all sites in winter. Concentrations of total chlorophyll and carotenoids were generally higher in samples from the polluted sites compared to the clean site. On the contrary, the concentration of carotenoids in lichens from the contaminated area in our findings was measured as the lowest. $\mathrm{SO}_{2}$ released from coal-fired thermal power plants was observed to reduce the chlorophyll a fluorescence in epiphytic lichen $P$. sulcata (Fernandez-Salegui et al. 2006).

Photosynthetic pigments are also influenced by climatic parameters (Paoli et al. 2010). Concentrations of $\mathrm{Chl}-\mathrm{a}, \mathrm{Chl}-\mathrm{b}$, and carotenoids in thalli of E. prunastri and P. furfuracea were found decreased with the decrease in altitude and along with the hottest and driest months of the year (Pirintsos et al. 2011). Concentrations of chlorophyll and carotenoid in the examined three lichen species in our study were lowest in urban area which altitude, rainfall and humidity is reduced, and temperature is increased.

Total chlorophyll content of $P$. furfuracea in Ankara was reduced with increasing of air pollution. Eventually, the concentration of Chl-a was decreased due to air pollution, and was a slight increase in the concentration of Chl-b (Yıldız et al. 2008).

The toxic effects of airborne pollutants on GST enzyme activities as one of the oxidative stress parameters were studied in the fruticose lichen $P$. furfuracea. As a result, GST enzyme activities and the protein content in polluted area were found higher than in the unpolluted area (Öztetik and Çiçek 2011). Although, the GST activity was increased in the lichen $P$. adscendens exposed to cadmium stres, total chlorophyll content was decreased compared with control thalli (Rustichelli et al. 2008).

\section{References}

Anonymous, 2011. Environmental indicators 2010, Republic of Turkey Ministry of Environment and Urbanisation, General Directorate of Environmen Impact Assessment, Permitting and Inspection, Department of Environmental Inventroy and Information Management, Ankara.

Anonymous, 2012. Provincial road traffic and travel information 2008-2012. Annual average daily traffic value and transport information according to provincial road traffic zone, Traffic Safety Department Presidency, Transportation Studies Branch Manager, Ankara.

Anonymous, 2013. Results of Address Based Population Registration System (ABPRS) (TurkStat, Turkey's Statistical Yearbook, 2013)

Ayrault, S., Clochiatti, R., Carrot, F., Daudin, L. and Bennett, J.P., 2007. Factors to consider for trace element deposition biomonitoring surveys with lichen transplants. Science of the Total Environment, 372, 717-727.

Bowman, B.P., Snell, T.W., and Cochrone, B.J., 1990. Isolation and purification of glutathione $\mathrm{S}$-transferase from Brachionus plicatilis and B. calyciflorus (Rotifera). Comparative Biochemistry and Physiology (Part B), 95, 619-629.

Bradford, M., 1976. A rapid and sensitive method for the quantification of micrograms quantities of protein utilizing the principle of protein-dye binding. Analytical Biochemistry, 72, 248-254.

Carreras, H.A., Gudino, G.L. and Pignata, M.L., 1998. Comparative biomonitoring of atmospheric quality in five zones of Cordoba city (Argentina) employing the transplanted lichen Usnea sp. Environmental Pollution, 103, 317-325.

Carreras, H.A. and Pignata, M.L., 2001. Comparison among air pollutants, meteorological conditions and some chemical parameters in the transplanted lichen Usnea amblyoclada. Environmental Pollution, 111, 45-52.

Conti, M.E. and Cecchetti, G., 2001. Biological monitoring: lichens as bioindicators of air pollution assessment a review. Environmental Pollution, 114, 471-92.

Fernandez-Salegui, A.B., Calatayud, A., Terron, A. and Barreno, E.M., 2006. Chlorophyll a fluorescence in transplants of Parmelia sulcata Taylor near a power station (La Robla, León, Spain). The Lichenologist, 38(5), 457-468.

Ferrat, L., Barelli, M.G., Martini, C.P. and Romeo, M., 2003. Mercury and non-protein thiol compounds in the seagrass Posidonia oceanica. Comparative Biochemistry and Physiology (Part C), 134, 147-155. 
Frati, L., Caprasecca, E., Santoni, S., Gaggi, C., Guttova, A., Gaudino, S., Pati, A., Rosamilia, S., Pirintsos, S.A. and Loppi, S., 2006. Effects of $\mathrm{NO}_{2}$ and $\mathrm{NH}_{3}$ from road traffic on epiphytic lichens. Environmental Pollution, 142, 58-64.

Garty, J., Karary, Y. and Harel, J., 1992. Effect of low pH, heavy metals and anions on chlorophyll degradation in the lichen Ramalina duriaei (De Not.) Bagl. Environ. Exp. Bot., 32, 229-241.

Garty, J., Tamir, O., Hassid, I., Eshel, A., Cohen, Y., Karnieli, A. and Orlovsky, L., 2001. Photosynthesis, chlorophyll integrity, and spectral reflectance in lichens exposed to air pollution. Journal of Environmental Quality, 30, 884-893.

Gauslaa, Y., Kopperud, C. and Solhaund, K.A., 1996. Optimal quantum yield of photosystem II and chlorophyll degradation of Lobaria pulmonaria in relation to $\mathrm{pH}$. Lichenologist, 28, 267-278.

Gilbert, N.L., Woodhouse, S., Stieb, D.M. and Brook, J.R., 2003. Ambient nitrogen dioxide and distance from a major highway. Science of the Total Environment, 312, 43-46.

Gilbert, N.L., Goldberg, M.S., Brook, J.R. and Jerrett, M., 2007. The influence of highway traffic on ambient nitrogen dioxide concentrations beyond the immediate vicinity of highways. Atmospheric Environment, 41, 2670-2673.

Giordani, P., Brunialti, G. and Alleteo, D., 2002. Effects of atmospheric pollution on lichen biodiversity (LB) in a Mediterranean region (Liguria, northwest Italy). Environmental Pollution, 118, 53-64.

Giordani, P., 2007. Is the diversity of epiphytic lichens a reliable indicator of air pollution? A case study from Italy. Environmental Pollution, 146, 317-323.

Giordano, S., Adamo, P., Sorbo, S. and Vingiani, S., 2005. Atmospheric trace metal pollution in the Naples urban area based on results from moss and lichen bags. Environmental Pollution, 136, 431-42.

Gombert, S., Asta, J. and Seaward, M.R.D., 2003. Correlation between the nitrogen concentration of two epiphytic lichens and the traffic density in an urban area. Environmental Pollution, 123, 281-290.

Habig, H.W., Pabst, J.M. and Jakoby, W.B., 1974. Glutathione S-Transferase: The first enzymatic step in mercapturic acid formation. Journal of Biological Chemistry, 249, 7130-7139.

Haffner, E., Lomsky, B., Hynek, V., Hallgren, J.E., Batı, F. and Pfanz, H., 2001. Air pollution and lichen physiology. Water, Air, and Soil Pollution, 131, 185201.

Jeffrey, S.W. and Humprey, G.F., 1975. New spectrophometric equations for determining chlorophyll a, b, c1, and c2 in higher plants, algae and natural populations. Biochem. Physiol. Pflanzen, 167, 191-194.

Karaer, F., 2011. The environment status report of TR41 region. Bursa Eskişehir Bilecik Development Agency (BEBKA).

Laurentin, A. and Edwards, C.A., 2003. A microtiter modification of the Anthrone-Sulphuric acid colorimetric assay for glucose-based carbohydrates. Analytical Biochemistry, 315, 143-145.

Lackovic, A., Guttova, A., Backor, M., Pisut, P. and Pisut, I., 2013. Response of Evernia prunastri to urban environmental conditions in Central Europe after the decrease of air pollution. The Lichenologist, 45(1), 89100.

Lichtenthaler, H.K. and Wellburn, A.R., 1985. Determination of total carotenoids and chlorophylls a and b of leaf in different solvents. Biol. Soc. Trans., 11, 591-592.

Llop, E., Pinho, P., Matosa, P., Pereirab, M.J. and Branquinhoa, C., 2012. The use of lichen functional groups as indicators of air quality in a Mediterranean urban environment. Ecological Indicators, 13, 215221.

Loppi, S., Ivanov, D. and Boccardi, R., 2002. Biodiversity of epiphytic lichens and air pollution in the town of Siena (Central Italy). Environmental Pollution, 116, 123128.

Munzi, S., Pirintsos, S.A. and Loppi, S., 2009. Chlorophyll degradation and inhibition of polyamine biosynthesis in the lichen Xanthoria parietina under nitrogen stress. Ecotoxicology and Environmental Safety, 72, 281-285.

Nimis, P.L., Lazzarin, G., Lazzarin, A. and Skert, N., 2000. Biomonitoring of trace elements with lichens in Veneto (NE Italy). Sci Total Environ, 255, 97-111.

Öztetik, E. and Çiçek, A., 2011. Effects of urban air pollutants on elemental accumulation and identification of oxidative stress biomarkers in the transplanted lichen Pseudoevernia furfuracea. Environmental Toxicology and Chemistry, 30(7), 1629-1636.

Oran, S. and Öztürk, Ş., 2012. Epiphytic lichen diversity on Quercus cerris and $Q$. frainetto in the Marmara region (Turkey). Turk J Bot, 36, 175-190.

Öztürk, Ş., Güvenç, Ş. and Aslan, A., 1997. Distribution of epiphytic lichens and sulphur dioxide $\left(\mathrm{SO}_{2}\right)$ pollution in the city of Bursa. Tr.J. of Botany, 21, 211-215.

Öztürk, M.Z., 2010. Comparative climate of Uludağ (Zirve) and Bursa Meteorology Stations. Türk Coğrafya Dergisi, 55, 13-24. 
Öztürk, Ş. and Güvenç, Ş., 2010. The distribution of epiphytic lichens on Uludag fir (Abies nordmanniana (Steven) Spach subsp. bornmuelleriana (Mattf.) Coode \& Cullen) forests along an altitudinal gradient (Mt. Uludag, Bursa, Turkey). Ekoloji, 19(74), 131-138.

Paoli, L. and Loppi, S., 2008. A biological method to monitor early effects of the air pollution caused by the industrial exploitation of geothermal energy. Environmental Pollution, 155, 383-388

Paoli, L., Pisani, T., Munzi, S., Gaggi, C. and Loppi, S., 2010. Influence of sun irradiance and water availability on lichen photosynthetic pigments during a Mediterranean summer. Biologia, 65, 776-783.

Paoli, L., Pisani, T., Guttova, A., Sardella, G. and Loppi, S., 2011. Physiological and chemical response of lichens transplanted in and around an industrial area of south Italy: relationship with the lichen diversity. Ecotoxicology and Environmental Safety, 74, 650657.

Pinho, P., Augusto, S., Branquinho, C., Bio, A., Pereira, M.J., Soares, A. and Catarino, F., 2004. Mapping lichen diversity as a first step for air quality assessment. Journal of Atmospheric Chemistry, 49, 377-389.

Pirintsos, S., Paoli, L., Loppi, S. and Kotzabasis, K., 2011. Photosynthetic performance of lichen transplants as early indicator of climatic stress along an altitudinal gradient in the arid Mediterranean area. Climatic Change, 107, 305-328.

Ra, H.S.Y., Geiser, L.H. and Crang, R.F.E., 2005. Effects of season and low-level air pollution on physiology and element content of lichens from the U.S. Pacific Northwest. Sci. Total Environ., 343(1-3), 155-167.

Riddell, J., Padgett, P.E. and Nash III, T.H., 2012. Physiological responses of lichens to factorial fumigations with nitric acid and ozone. Environmental Pollution, 170, 202-210.

Rustichelli, C., Visioli, G., Kostecka, D., Vurro, E., di Toppi, L.S. and Marmiroli, N., 2008. Proteomic analysis in the lichen Physcia adscendens exposed to cadmium stres. Environmental Pollution, 156, 1121-1127.

Seed, L., Wolseley, P., Gosling, L., Davies, L. and Power, S.A., 2013. Modelling relationships between lichen bioindicators, air quality and climate on a national scale: Results from the UK OPAL air survey. Environmental Pollution, 182, 437-447.

Shukla, V. and Upreti, D.K., 2007. Physiological response of the lichen Phaeophyscia hispidula (Ach.) Essl., to the urban environment of Pauri and Srinagar (Garhwal), Himalayas, India. Environmental Pollution, 150, 295-299.

Shukla, V. and Upreti, D.K., 2008. Effect of metallic pollutants on the physiology of lichen, Pyxine subcinerea Stirton in Garhwal Himalayas. Environ Monit Assess., 141, 237-243.

Taşdemir, Y., 2002. Air Pollution Caused by Sulfur Dioxide in Bursa. Ekoloji Çevre dergisi, 11(42), 12-15.

Tretiach, M., Piccotto, M. and Baruffo, L., 2007. Effects of ambient NOx on chlorophyll a fluorescence in transplanted Flavoparmelia caperata. Environmental Science \& Technology, 41(8), 2978-2984.

TSMS, 2018. Climate data of Bursa province (Period of 1926-2016). Turkish State Meteorological Service (TSMS), Ankara.

van Herk, C.M., 2001. Bark pH and susceptibility to toxic air pollutants as independent causes of changes in epiphytic lichen composition in space and time. Lichenologist, 33(5), 419-441.

van Herk, C.M., Aptroot, A. and van Dobben, H.F., 2002. Long-term monitoring in the Netherlands suggests that lichens respond to global warming. Lichenologist, 34(2), 141-154.

von Arb, C., Mueller, C., Ammann, K. and Brunold, C., 1990. Lichen physiology and air pollution II. Statistical analysis of the correlation between $\mathrm{SO}_{2}, \mathrm{NO}_{2}, \mathrm{NO}$ and $\mathrm{O}_{3}$ and chlorophyll content, net photosynthesis, sulphate uptake and protein synthesis of Parmelia sulcata Taylor. New Phytol., 115, 431-437.

Yıldız, A., Aksoy, A., Tug, G.N., Islek, C. and Demirezen, D., 2008. Biomonitoring of heavy metals by Pseudevernia furfuracea (L.) Zopf in Ankara (Turkey). J Atmos Chem., 60, 71-81. 